\title{
POLA ASUH ANAK USIA DINI DAN PERSPEKTIF NILAI BUDAYA
}

\author{
Irma (70200120086)
}

Universitas Islam Negeri Alauddin Makassar

Kesehatan Masyarakat Kelas C

Email: irmaaprilia26@gmail.com

\section{A. Pendahuluan}

Perkembangan anak dalam masa ini berada dalam suatu kehidupan yang rentan, sehingga peran keluarga sangat penting untuk membantu proses pertumbuhan dan perkembangan anak usia dini. Budaya merupakan wadah bagi sekelompok masyarakat dalam membungkus nilai- nilai yang mereka miliki. Nilai- nilai ini menjadi bagian yang penting bagi para orang tua dalam mengasuh anak mereka. Konstruksi sosial orang tua tentang pendidikan merupakan konsep pendidilan formal yang dibangun oleh orang tua dalam keluarga terhadap anak dengan menyertakan faktor sosial budaya masyarakat. Pola asuh yang tepat akan membentuk kepribadian dan perilaku sosial yang baik pada anak. Perilaku maupun perlakuan orang tua terhadap anak merupakan faktor yang sangat berpengaruh terhadap perkembangan anak, terkait dengan cara bagaimana orang tua mendidik dan membesarkan anak (Gunarsa, 2000). Dalam berinteraksi dengan anak, orang tua dengan tidak sengaja atau tanpa disadari mengambil sikap tertentu.

Pada masyarakat budaya, manusia membentuk keluarga, membesarkan anakanak, serta berusaha untuk meneruskan nilai- nilai untuk kesuksesan anak dan orang lain di masa yang akan datang (Edwards, Knoche, Aukrust, Kumru, \& Kim, 2010). Nilainilai yang diturunkan ini disebutkan sebagai kurikulum budaya oleh Nsamenang (dalam Edwards, et. al, 2010). Anak- anak mempelajari nilai-nilai yang diturunkan melalui konteks lingkungan disekitar mereka. Nilai- nilai yang terbentuk ini selama masa periode tertentu akan membentuk gaya tersendiri pada diri anak dalam kehidupan sehari- hari.

Pola asuh sendiri, dapat diartikan sebagai cara dalam penataan lingkungan fisik, lingkungan sosial, interaksi dengan anak-anak, suasana psikologis, sosial budaya, perilaku yang ditampilkan pada saat adanya pertemuan dengan anak-anak, serta menentukan nilai-nilai moral sebagai dasar berperilaku anak (Shochid, 2010). Pemahaman ini juga dikuatkan dengan telah lintas budaya yang menunjukkan situasi 
dalam keluarga dan gaya pengasuhan akan mempengaruhi kondisi psikologis anak (Dayakisni \& Yuniardi, 2012). Sehingga, keluarga memiliki peran penting dalam perkembangan individu.

\section{B. Faktor Yang Penghambat Pengasuhan Anak Dengan Orangtua}

Teknik menyusui merupakan satu faktor yang mempengaruhi produk ASI dimana bila teknik menyusui tidak benar dapat menyebabkan putting lecet dan menjadikan ibu enggan menyusui dan bayi jarang menyusui karena bayi enggan menyusu akan berakibar kurang baik, karena isapan bayi sangat berpengaruh pada rangsangan produksi ASI selanjutnya, namun sering kali ibu-ibu kurang mendapatkan informasi tentang manfaat ASI dan tentang teknik menyusui yang benar. Faktor yang mempengaruhi dalam pemberian ASI diantaranya usia ibu, pendidikan ibu, pengetahuan ibu, pekerjaan ibu, dan paritas ibu. Pengetahuan ibu tentang teknik menyusui yang benar sangat penting sebab dari pengalaman dan penelitian terbukti bahwa perilaku yang didasari pengetahuan akan lebih langsung daripada perilaku yang tidak disadari oleh pengetahuan. Pada penelitian ini dilakukan perhitungan dan teknik menyusui pada anak. Berdasarkan hasil uji Chi Square diperoleh nilai $\mathrm{p}$ adalah $0,000>0,05$. Dengan demikian maka Ho ditolak hubungan kebiasaan mencuci tangan sebelum mengecerkan susu formula dengan kejadian diare pada bagi di desa Dannuang kec. Ujung Loe kab. Bulukumba Tahun 2016. Dipeolrh Sig $(0,16)$ lebih besar dari alpha $(0,05)$ berarti hubungan yang bermakna antara kebiasaan mencuci tangan sebelum mengencerkan susu dengan kejadian diare pada anak.

Maraknya single parent atau orangtua yang tunggal yang terjadi dalam masyarakat sekarang ini seperti telah menjadi hal umum dan suatu hal yang wahar atau sangat biasa dikalangan masyarakat. Single parent atau biasa disebut dengan orangtua tunggaladalah seorang ayah atau ibu yang memikul tugasnya sendiri sebagai kepala keluarga sekaligus menjadi seorang ibu rumah tangga, beserta bertanggung jawab atas segala aspek kehidupan sang anak, sampai pendidikannya sekalipun dengan memberikan pertanggungjawaban atas hak anak untuk mendapatkan pendidikan yang layak. Orangtua tunggal sesungguhnya penting memahami anak dari usia dini karena nantinya akan berpengaruh pada masa remajanya kelak, apalagi akhir-akhir ini sudah pengetahuan umum banyak terjadi kenakalan remaja yang disebabkan kurangnya perhatian atau pun pendidikan moral yang anak- anak dapatkan. Inilah beban terberat bagi seorang orangtua tunggal.Kondisi semacam ini munculnya rasa kurang percaya 
pada orang tua dan selalu mencari jalan masalahnya sendiri, bisa jadimereka terlibat dalam pergaulan yang buruk karena kurangnya kontrol orangtua. Moralitas orangtua dalam keluarga menjadi salah satu contoh pendidikan moral yang diajarkan orangtua pada anak karena anak-akan secara alami menyerap apa yang dilakukan orang tua. Pendidikan moral tersebut dikatakan pendidikan nonformal tetapi akan sangat membekas pada diri anak. Maka sangat sulit ketika orangtua harus mendidik anak sendirian karena memaksa orangtua tunggal tersebut harus berperan ganda dalam keluarga untuk sang anak.

Peran orang tua dan pengasuhan anak seringkali berlangsung dalam kondisikondisi yang sangat berbeda di negara dan budaya- budaya yang berbeda. Kondisi ini akan menghasilkan proses sosialisasi yang berbeda dari satu budaya dan budaya lainnya. Perbedaan dalam pengasuhan anak ini tidak hanya terjadi karena perbedaan keyakinan dan nilai- nilai saja, tetapi juga perbedaan yang nyata dalam taraf kehidupan. Salah satu faktor yang mempengaruhi praktik pengasuhan anak adalah kondisi ekonomi keluarga. Bayi-bayi yang masih berusia beberapa minggu di Cina akan ditinggalkan oleh ibunya untuk bekerja di ladang. Mereka dibaringkan pada sak-sak pasir yang lebar sehingga dapat menyokong tubuh sekaligus sebagai popok penyerap (Matsumoto, 2008). Ini tidak terlihat kejam bagi mereka meninggalkan anak seharian untuk bekerja. Kondisi perekonomian yang tidak baik akan mengarahkan upaya pengasuhan yang berfokus pada memenuhi kebutuhan primer manusia.

Selain faktor ekonomi, struktur keluarga juga menjadi faktor lain yang perlu diperhatikan dalam pola pengasuhan. Perbedaan budaya akan mempengaruhi struktur keluarga sebagai salah satu faktor dari pola pengasuhan. Pengasuhan dalam keluarga extended tentu akan berbeda dengan pengasuhan yang dilakukan dalam keluarga inti. Meskipun ibu merupakan pengasuh utama dalam keluarga, namun keluarga extended akan memungkinkan seorang anak juga mendapatkan pengasuhan dari keluarga lainnya, seperti kakek-nenek, saudara atau pun kerabat lainnya. Praktik pengasuhan seperti ini, menunjukkan bagaimana proses pewarisan budaya yang disampaikan dari, generasi ke generasi berikutnya (Matsumoto, 2008).

Budaya dan teknologi bersama dengan peningkatan modernisasi akan menciptakan penurunan variasi budaya yang tersedia untuk individu. Dan secara bersamaan ini dapat memberi kesan reduksi keragaman budaya (Newson, Richerson, \& 
Boyd, 2010). Hal ini dapat terjadi karena interaksi yang sering terjadi oleh kelompokkelompok dengan budaya yang berbeda baik secara langsung, juga melalui teknologi sebagai media. Praktik pengasuhan yang dilakukan orang tua dalam dunia modernisasi dapat membentuk generasi- generasi dengan variasi budaya yang minim. Sehingga proses penurunan budaya dari generasi yang satu ke generasi lainnya akan menciptakan kebudayaan baru dengan keunggulan teknologi. Penelitian yang dilakukan pada ibu-ibu yang tinggal dipedesaan sebagai agen perubahan budaya dalam mendidik anak-anaknya. Mereka melakukan adaptasi melalui pembelajaran pada sekolah formal mengenai konsep " anak baik" . Para ibu modern akan mengartikannya sebagai perilaku ingin tahu, percaya diri, serta mandiri. Ini menggeser nilai-nilai tradisional seperti, penuh hormat, patuh, murah hati, dan baik hati (Edwards, Knoche, Aukrust, Kumru, \& Kim, 2010). Modern dan tradisional disini dilihat dengan gaya hidup yang merujuk pada faktor ekonomi sosial dan teknologi.

Penelitian ini bertujuan untuk mengetahui gambaran nilai- nilai budaya dalam membentuk pola asuh didalam suatu keluarga. Manfaat yang dapat diambil dari penelitian ini secara teoritis adalah untuk menambah kajian keilmuan psikologi, khususnya kajian psikologi sosial. Serta manfaat praktis sebagai gambaran nilai- nilai yang diajarkan oleh keluarga untuk diinternalisasi oleh mahasiswa sebagai subjek penelitian.

\section{Metode Penanaman Nilai Budaya Dalam Pengasuhan Anak}

Nilai- nilai Budaya dalam Lingkungan Padangsitang (Keluarga) dan Penerapannya Nilai- nilai budaya dalam proses pengasuhan anak yang dianggap penting dalam lingkungan keluarga. Nilai- nilai budaya tersebut ditunjukkan pada Tabel 1 berikut ini:

\begin{tabular}{|c|c|c|}
\hline No & Nilai Budaya & Makna/Arti \\
\hline 1 & Sikarimanang & Kasih saying (saling menyayangi) \\
\hline 2 & Sikadampahang & Cinta (saling mencintai \\
\hline 3 & Situnggu & Kesetiaan \\
\hline 4 & Siangnga & Hormat (saling mmenghormati) \\
\hline
\end{tabular}




\begin{tabular}{|c|c|c|}
\hline 5 & Situngka & Merawat (menjaga satu sama lain) \\
\hline 6 & Sijampangi & Mengasuh (saling asuh) \\
\hline 7 & Sisaile & Perhatian \\
\hline
\end{tabular}

Berdasarkan Tabel 1, masyarakat memiliki sejumlah nilai- nilai budaya pengasuhan dan pendidikan dalam keluarga yakni Nila sikarimanang yang bermakna kasih sayang atau saling menyayangi. Nilai budaya ini pada intinya menekankan perlunya cinta, kasih sayang serta kesetiaan pada pengasuhan dalam keluarga. Makna cinta dan kasih sayang dalam pengasuhan dalam suatu penelitian yang dilakukan oleh Gerhardt (2009: 8) menekankan bahwa cinta dan kasih sayang menjadi hal yang sangat penting dalam kehidupan anak.Nilai berikutnya adalah situnggu' yang secara bahasa berarti menunggu atau menanti. Dalam pengertian lebih lanjut, situnggu' berarti bermakna kesetiaan atau tidak meninggalkan satu sama lain. Bahwa dalam konsep pengasuhan makna kesetiaan. Makna kesetiaan adalah cermin kebahagiaan di dalam hidup seseorang. Demikian halnya dalam suatu keluarga. Kesetiaan berarti kebahagiaan yang begitu teramat mendalam, mengarungi bahtera rumah tangga. Kebahagiaannya begitu bermakna justru bukan dalam kegembiraan namun disaat keluarganya sedang diuji atau menghadapi masalah. Kekuatan cinta karena akan mampu melewati semua derita, menanggung beban dalam suka maupun duka, hidup bersama dalam keluarga dalam mengasuh anak. Karakeristik keluarga yang kuat dalam pengasuhan anak selanjutnya adalah siangnga' . Secara etomologi kata ini berarti saling menempatkan pada suatu tempat. Pengertiannya adalah bahwa seseorang harus dipandang sebagaimana mestinya. Nilai saling memanusiakan ini dikarenakan karena adanya rasa hormat (resfectful). Penelitian Akabas (1990: 12) yang ditulis dalam - Resfectful Parent- Resfectful Child॥ mempertegas bahwa jika orang tua melakukan pengasuhan dalam suasana yang respek maka akanberdampak kepada lahirnya rasa hormat seorang anak. Untuk itu, dalam rangka membangun suasana keharmonisan dalam keluarga maka hubungan anggota dalam keluarga harus diciptakan dalam suatu hubungan yang penuh rasa hormat. Disebutkan bahwa straregi untuk menjaga stabilitas kehormatan dalam keluarga dibutuhkan sikap yang konsisten dan berkesinambungan. Temuan nilai berikutnya dinamakan sijampangi (saling mengurus satu sama lain). Nilai budaya ini menekankan perlunya memberikan perhatian dan 
waktu dalam hal pengasuhan dan pendidikan anak. Anak yang kurang mendapatkan perhatian yang berarti dalam hidupnya cenderung merasa asing dan teralienasi. Akibatnya kadang kala anak melakukan kompenasi atau tindakan sendiri sebagai bentuk palampiasan dan dipandang sebagai pembalasan dendam. Nilai berikutnya adalah sisaile yang secara bahasa bermakna melihat atau melirik. Pengertian lebih lanjut nilai sisaile ini berarti senantiasa melihat atau melirik dan tidak mengabaikan. Nilai pengasuhan ini terwujud dalam bentuk perhatian dan simpati. Dalam suatu pengasuhan maka nilai perhatian tidak dapat diabaikan. Makna nilai budaya ini adalah bahwa dalam keluarga diperlukan wujud saling memperhatikan satu sama lain. Sementara itu, Brigard \& Prinz (2009: 51) mengemukakan bahwa perhatian akan memberikan efek kesadaran, selain itu perhatian ini lebih lanjut disebutkan sangat dipengaruhi oleh persepsi sesorang dalam menilai sesuatu yang dipersepsikan. Nilai dalam keluarga sebagaimana ditemukan dalam masyarakat Bajo ini adalah nilai- nilai yang siginifikan dalam konteks pendidikan keluarga masyarakat Bajo ini juga disebutkan bahwa guna mendukung proses pembelajaran anak, maka strategi yang sangat penting adalah mengembangkan kemitraan dan komitmen.Kemitraan orang tua adalah hal yang mutlak terutama dalam konteks keragaman latar belakang suku etnik dalam program pendidikan anak (Henderson \& Mapp, 2002: 16).

Performa Orangua Dalam Mengasuh Anak Perspektif Nilai Budaya Tabel 2

\begin{tabular}{|c|c|c|}
\hline No & $\begin{array}{c}\text { Performa Orangtua Perspektif Nilai } \\
\text { Budaya }\end{array}$ & Makna/Arti \\
\hline 1 & Kasabarenne/diala maupa & Kesabaran \\
\hline 2 & Lantah & Kejujuran \\
\hline 3 & Tunggah & Kepatuhan/kepantasan//kelayakan \\
\hline 4 & Paturu' & Keteguhan/ketegasan \\
\hline
\end{tabular}

menunjukkan bahwa dalam implementasi pengasuhan, masyarakat Bajo memegang teguh nilai buda- ya sebagai nilai yang telah mengkristal dalam kehidupan masyarakat secara universal. Nilai kasabaranne atau diala maupa' secara bahasan berarti sabar atau mengambil hikmah dari suatu kejadian serta mengambil untungannya. Lebih lanjut nilai ini dapat diartikan sebagai sikap yang senantiasa bersabar dan mencoba mengambil nilai hikmah atau mengedepankan pikiran positif (positive thinking). Perwujudan nilai kesabaran dan menemukan hikmah dibalik suatu kejadian lebih 
disebabkan oleh lahirnya pikiran positif terhadap suatu peristiwa atau kejadan. Naseem \& Khalid (2010:44) dalam penelitian tentang pikiran positif menegaskan bahwa berpikir positif sangat erat hubungannya dengan psikologi manusia dimana dalam wujudnya dilakukan dengan cara menghilangkan sangkaan atau pikiran negative dalam diri manusia. Lebih lanjut disebutkan bahwa implikasi dari berpikir positif ini akan melahirkan keseimbangan diri secara emosional serta mempengaruhi seseorang dalam bertindak dan berprilaku. Nilai kasabaranne sebagai nilai pada masyarakat Bajo nampaknya memang menjadi suatu fenomena yang menjadi karakter manusia Bajo. Nilai lantah secara harfiah berarti jujur. Nilai kejujuran merupakan nilai yang sangat dipegang teguh dalam kehidupan masyarakat tradesional seperti masyarakat Bajo. Perwujudan nilai kejujuran dalam penelitian Somanathan dan Rubin (2004: 1- 17) perlu disosialisasikan melalui pembiasaan dan modeling dimana orang tua dalam lingkungan disebutnya senantiasa " menyembunyikan" ketidakjujuran. Selanjutnya ditemukan bahwa jika anak diajari lebih awal terhadap nilai kejujuran ini maka akan membekas dan bertahan lama dalam pola pembentukan perilaku anak. Nilai kejujuran melalui sosialisasi akan berevolusi seiring dengan upaya orang tua dalam membentuk pribadi anak yang jujur dalam kehidupan. Konsepsi nilai-nilai tentang kejujuran, dapat pula ditemukan dalam berbagai suku atau kelompok masyarakat di Indonesia. Dalam masyarakat Bugis Makasssar misalnya, penjelasan mengenai beberapa konsep nilainilai lantah (kejujuran) dapat dilihat dalam lontarak (Alang, yang antara lain menjelaskan tentang kejujuran sebagaimana dikatakan sebagai berikut: eppa gaunna lempu' narisalie maddampeng, riparennuangi temmaceko bettuanna teppabbelleang, temmangoani tania olona, to naseng deceng rekko nassamarini pudecengi (Ada empat ciri perilaku jujur : (a) memafkan orang yang berbuat salah kepadanya, (b) jika dipercaya tidak berlaku curang atau dalam pengertian bahwa jika diberikan amanah tidak mengingkarinya, (c) tidak serakah kepada yang bukan haknya dan (d) tidak memandang suatu kebaikan kalau hanya bersumber dari dirinya). Konsepsi kejujuran juga dituliskan dalam bentuk uraian lain seperti: - Eppa sappo wanuae, tennaullei muttamakiwi to maelo maggau bawange. Seuani, lempu' na silaong ade' , maduanna rapange nasilaong getteng. Matellunna, awaraningeng nasibawai amaccang ma maeppana, labo nasibawangi palece (Ada empat hal yang dapat dijadikan sebagai pagar sehingga tidak akan dimasuki oleh orang-orang yang berniat tidak baik yakni kejujuran bersama dengan adat, sandaran yang kuat yang didukung oleh keteguhan hati, ketiga keberanian yang disertai dengan pengetahuan dan yang keempat adalah 
sifat pemurah bersama dengan ketulusan dan keikhlas).

Dalam hal metode penanaman nilai- nilai budaya dalam pendidikan dan pengasuhan anak pada masyarakat Bajo terdapat sejumlah metode sebagaimana ditunjukkan pada Tabel berikut:

\begin{tabular}{|c|c|c|}
\hline No & Metode penanaman nilai budaya & Makna/Arti \\
\hline 1 & Dituhu anu ma' ale' & Keteladanan/mencontohkan \\
\hline 2 & Pakabiase & Pembiasaan \\
\hline 3 & Pmara' & Nasehat dalam bentuk \\
& & cerita/dogeng \\
\hline
\end{tabular}

Berdasarkan Tabel diatas terlihat bahwa terdapat sejumlah metode penanaman dalam menginternalisasikan nilai- nilai budaya dalam pengasuhan dan pendidikan anak dini usia diantaranya dituhu anu ma' ale yang secara bahasa berarti dicontoh atau ditiru, sedang secara terminologis bermakna nilai keteladanan atau hal yang dapat diteladani.

Nilai keteladanan ini menurut konsepsi Islam sebagai sumber konsep bagi seorang muslim (seperti juga masyarakat Bajo) menjadikan konsep keteladanan sebagai salah satu metode dalam mendidik anak. Konsep tentang keteladan dalam Al Qur"anul Karim sebagaimana ditegaskan, "Sesungguhnya telah ada pada (diri) Rasulullah itu suri teladan yang baik bagimu". Nilai budaya berikutnya adalah pakabiase atau pembiasaan. Menurut Sholen \& Thener (2006: 12) bahwa banyak psikolog tahu tentang persepsi dan kognisi bayi didasarkan pada habituasi, tetapi proses itu sendiri masih kurang dipaham.

Dalam penelitiannya, tentang dinamis visual bayi disimulasikan fitur yang dikenal dengan istilah pembiasaan. Pembiasaan dipandang sebagai keakraban dan kebaruan efek yang lahir karena intensitas stimulus. Sementara itu Haines (2005:8) mengatakan bahwa, untuk mengubah norma sosial yang tidak baik sangatlah sulit dan untuk itu perlu adanya eksposes masyarakat melalui pesan norma untuk merubah kebiasaan yang dianggap negatif dengan melalui suatu pendekatan yang berulang- ulang (pembiasaan).

Konsepsi yang berikutnya sebagai bagian dari pembiasaan dan kebiasaan adalah adat (istiadat). Koentjaraningrat (1977:206) mengatakan bahwa salah satu sistem 
pengendalian sosial dalam kehidupan masyarakat dalam garis besarnya yang mengatur kompleksitas masyarakat adalah adat istiadat. Istilah tradisi sering digunakan dengan cara deskriptif, sementara kadang-kadang dituntut untuk menghasilkan kilasan peristiwa atau sejarah. Tradisi dianggap oleh kaum konservatif terdiri dari kebijaksanaan akumulasi yang seharusnya muncul secara organik dari pengalaman dalam wujud trial and error (Burke, 1789: 79).Tradisi dipandang sebagai jejaring keyakinan orang-orang yang diwarisi dan yang mempengaruhi bagaimana mereka kemudian memahami dunia.

Nilai berikutnya adalah pamara' atau na- sehat. Nilai merupakan merupakan penyampaian pesan- pesan yang bernilai kebaikan baik secara lisan maupun tulisan sebaga pembawa pesan moral baik yang disampaikan secara langsung ataupun tidak langsung. Inti nasehat terletak pada pesan yang baik. Jika ada sesuatu kejadian kadang kala bermakna nasehat dan mencoba mengambil pelajaran didalamnya yang juga disebut dengan hikmah. Jadi konsepsi nasehat sebagai salah satu metode dalam pendidikan anak merupakan tuntunan ajaran Islam sebagai agama yang dianut oleh masyarakat Bajo. Konsepsi pamara' dalam konteks masyarakat Bajo makna pamara sama dengan konteks pangaja dalam bahasa Bugis. Metode ini dipandang sebagai metode yang menekankan pada perlunya kedekatan emosi antara orang tua dengan anak. Bagi anak usia dini sejak harus dilakukan sekalipun dalam bentuk sederhana untuk menyampaikan kepada anak hal- hal yang boleh dilakukan dan dihindari..

\section{Kesimpulan}

Berdasarkan temuan penelitian dan pembahasan maka beberapa hal yang menjadi kesimpulan penelitian ini adalah sebagai berikut. 1) Nilai- nilai budaya dalam proses pengasuhan anak yang dianggap penting dalam lingkungan keluarga adalah sikarimanang (kasih dan sayang), sikap dampahang (saling mencintai), situnggu (kesetiaan), siangnga (Saling hormat), situngka (merawat), sijampangi (mengasuh) dan sisaile (perhatian). Nilai- nilai budaya yang demikian ini perlu digali dan dilestarikan sebagai nilai- nilai yang sangat luhur yang tidak dapat diabaikan dalam pendidikan dan pengasuhan anak usia dini. 2) Orangtua (ayah/ibu) dalam keluarga senantiasa menunjukkan performa (perilaku) yang sesuai dengan nilai budaya yang dianggap penting ditanamkan sebagai proses pendidikan dan pengasuhan yakni kasabaranne atau diala maupa (kesabaran), lantah (kejujuran), dan Tuggah (tegas). Hal ini 
merupakan nilai yang teramat penting untuk diinternalisasikan dalam praktek pendidikan dan pengasuhan anak sebagai nilai warisan leluhur. 3) Metode yang digunakan dalam menanamkan nilai budaya oleh masyarakat Bajo meliputi dituhu anu ma' ale (keteladanan), pakabiase (pembiasaan) dan pamara' atau nasehat. Oleh sebab itu pelunya menerapkan nilai- nilai budaya tersebut sebagai model penanaman nilai- nilai budaya dalam pendidikan dan pengasuhan anak usia dini. 


\section{Daftar Pustaka}

Muhammad Akil Musi, dkk. 1 Juni 2015. Pengasuhan Anak Usia Dini Prespektif Nilai Budaya Pada Keluarga Bajo Di Kabupaten Bone https://ojs.unm.ac.id/Insani/article/download/3601/2018

Minati Etika Marlin. 2016. Kontruksi Soaial Orang Tua Temtang Pendidikan Dan Pola Asuh Anak Keluarga Nelayan https://journal.unnes.ac.id/sju/index.php/jess/article/download/14080/7698

Masturah Nabila Alifah. Pola Asuh Pada Mahasiswa Ditinjau Dari Prespektif Budaya https://publikasi.mercubuana.ac.id/index.php/biopsikososial/article/view/2166

Agnes Indra Etikawati, dkk.September 2019

https://journal.ipb.ac.id/index.php/jikk/article/download/25700/17879//

Hilda Septia Ningsih. Budaya pengasuhan anak dalam keluarga di kelurahan kampong dagang kecamatan rengat https://jom.unri.ac.id/index.php/JOMFKIP/article/view/6555

Alam, Syamsul and Kartini, Tri Addya. 2020. Tinjauan Perspektif Gizi Masyarakat http://repository.uin- alauddin.ac.id/17794/

Alam, Syamsul and Syahrir, Sukfitriani. 2 Juli 2016. Faktor- Faktor Berhubungan Dengan Teknik Menyusui Pada Ibu Di Puskemas Pattallasang Kabupaten Takalarhttp://103.55.216.56/index.php/Al- Sihah/article/view/2649

Alam, Syamsul and Syahrir, Sukfitriani. 2 Mei 2017. Hubungan Personal Hygiene Pemberian Susu Formula Dengan Kerjadian Diare Pada Bayi Di Kelurahan Dannuang Kecamatan Ujung Loe Kabupaten Bulukumba Tahun 2016 http://103.55.216.56/index.php/Al-Sihah/article/view/3699 